\title{
PENGARUH PEMBERIAN VAKSIN BCG SECARA ORAL DAN SUBKUTAN TERHADAP KOMPONEN SELULER DAN HUMORAL PADA Rattus norvegicus GALUR WISTAR
}

\author{
Netti Suharti, Andani Eka Putra \\ Bagian Mikrobiologi Fakultas Kedokteran Universitas Andalas \\ email : netti_suharti@yahoo.co.id
}

\begin{abstract}
Abstrak
Vaksinasi BCG merupakan metoda pencegahan infeksi M. tuberculosis dengan rentang efektivitas antara $0-80 \%$. Vaksin ini bekerja dengan menginduksi sistem imunitas seluler, terutama sel limfosit $\mathrm{T}$. Beberapa faktor yang mempengaruhi efektivitas vaksin, seperti bahan dasar, rute pemberian, penyimpanan dan lain sebagainya.penelitian ini bertujuan untuk menilai pengaruh rute vaksinasi BCG, per oral dan subkutan terhadap imunitas seluler dan humoral, yang meliputi pembentukan antibodi, kosentrasi sel limfosit $\mathrm{B}, \mathrm{T}$ dan penilaian kemampuan makrofag.

Penelitian eksperimental yang dilaksanakan dengan mengunakan desain post test only control group design. Jumlah sampel 10 ekor Rattus norvegicus galur Wistar. Antibodi diperiksa dengan menggunakan ELISA, serta dilakukan uji statistik mengunakan t-test.

Didapatkan kadar antibodi kelompok subkutan pada hari ke-10 adalah OD $1.714 \pm$ 0.124 , sedangkan kelompok oral adalah $1.256 \pm 0.243$ dan pada kontrol kadar antibodi adalah $0.975 \pm 0.253$ ( $\mathrm{p}<0.05$ ). Jumlah limfosit B pada kelompok subkutan adalah $4.5 \times 10^{3} \mathrm{sel} / \mathrm{ml}$, kelompok oral $2.6 \times 10^{3} \mathrm{sel} / \mathrm{ml}$ dan kontrol 2.2. x $10^{3} \mathrm{sel} / \mathrm{ml}(\mathrm{p}<0.05)$. Jumlah limfosit $\mathrm{T}$ kelompok subkutan adalah $3.8 \times 10^{4}$ $\mathrm{sel} / \mathrm{ml}$ sedangkan pada kelompok oral dan kontrol, masing-masing adalah $1.1 \mathrm{x}$ $10^{4} \mathrm{sel} / \mathrm{ml}$ dan $0.8 \times 10^{4} \mathrm{sel} / \mathrm{ml}(\mathrm{p}<0.05)$. Kemampuan fagositosis makrofag subkutan adalah $62.5 \pm 6.8$ lebih tinggi dibanding kelompok oral $48.7 \pm 5.8$ dan kontrol $35.6 \pm 4.4$ ( $\mathrm{p}<0.05)$. Fenomena yang sama ditemukan pada hari ke-20. Namun demikian tidak ditemukan perbedaan konsentrasi seluruh variabel seluler dan humoral antara hari ke-10 dan 20 ( $\mathrm{p}>0.05)$.

Vaksinasi BCG akan meningkatkan respon imunitas seluler dan humoral dan rute vaksinasi subkutan lebih baik dibanding per oral ditinjau dari aspek respon imun.

Kata kunci : Vaksinasi BCG, seluler, humoral, makrofag
\end{abstract}

\section{Abstract}

BCG vaccine is a method to prevent the infection of $\mathrm{M}$ tuberculosis with effectiveness range between $0-80 \%$. This vaccine works with inducing cellular immunity system, mainly in cell of Lymphocyte $\mathrm{T}$. There are many factors that 
influence the vaccines affectivity, such as basic substance, giving route, and storage.

This experiment is conducted in to Rattus norvegicus Wistar Furrow in order to examine the effect of the route of BCG vaccination's in oral and sub cutaneous to cellular and humoral immunity, which covers the formation of antibody, lymphocyte B cell concentration, and the evaluation of macrophage capability.

This experiment's result shows that the antibody of sub cutaneous groups on day $10^{\text {th }}$ is OD $1.714 \pm 0.124$, and $1.256 \pm 0.243$ in oral, while in antibody control is $0.975 \pm 0.253$ ( $\mathrm{p}<0.05$ ). The amount of Lymphocyte B in sub cutaneous group is $4.5 \times 10^{3} \mathrm{cell} / \mathrm{ml}, 2.6 \times 10^{3} \mathrm{cell} / \mathrm{ml}$ in oral and $2.2 \times 10^{3}$ cell $/ \mathrm{ml}(\mathrm{p}<0.05)$ in control. The amount of Lymphocyte $\mathrm{T}$ in sub cutaneous is $3.8 \times 10^{4}$ cell $/ \mathrm{ml}$, while in oral and control is $1.1 \times 10^{4} \mathrm{cell} / \mathrm{ml}$ and $0.8 \times 10^{4} \mathrm{cell} / \mathrm{ml}(\mathrm{p}<0.05)$. The phagocytosis ability of sub cutaneous's macrophage is $62.5 \pm 6.8$ which is higher than oral group $48.7 \pm 5.8$ and control $35.6 \pm 4.4(\mathrm{p}<0.05)$. The same phenomenon also found in day $20^{\text {th }}$. However, the difference concentrations of the entire cellular and humeral variable between day $10^{\text {th }}$ and day $20^{\text {th }}(p<0.05)$ has not been found.

Based on the result of this experiment's it can be concluded that BCG vaccination will increase the cellular and humeral immunity response and sub cutaneous's vaccination route is better that oral, from immunes response aspect side.

Key word : BCG Vaccination, cellular, humeral, macrophage. 


\section{PENDAHULUAN}

Bacille CaImette-Guérin (BCG) merupakan vaksin yang umum digunakan untuk penyakit tuberkulosis, mulai dikembangkan pada tahun 1906 oleh Albert Calmette dan Camilla Guerin. Vaksin ini dibuat dari Mycobacterium Bovis yang dilemahkan dan pertama kali diberikan secara oral pada tahun 1921 pada bayi yang baru lahir dengan ibu yang meninggal akibat TB Paru. Vaksin ini mampu melindungi bayi hingga dewasa dalam rangka pencegahan tehadap penyakit tuberkulosis. WHO merekomendasikan pemberian vaksin BCG yang diberikan saat lahir atau beberapa saat setelah lahir. Tahun 2002, imunisasi BCG telah dilakukan lebih dari $90 \%$ negara di dunia. Diperkirakan 100.5 juta anak (76\%) dari total 132.8 juta anak telah mendapatkan imunisasi BCG. ${ }^{(1-4)}$

Efektivitas proteksi vaksin BCG bervariasi antara $0-80 \%$. Pola proteksi seperti ini menunjukkan bahwa vaksin ini masih mempunyai banyak kelemahan, dan dibutuhkan perbaikan segera, namun permasalahan utama adalah masih sedikitnya informasi tentang mekanisme proteksi terhadap tuberkulosis. Perkembangan imunologi yang masih dipegang hingga saat sekarang ini adalah adanya respon imun seluler yang diperantarai oleh Interferon (IFN) $\gamma$ dan Interleukin 2 (IL-2) yang dihasilkan oleh sel $\mathrm{CD}^{+}$Limfosit $\mathrm{T}$, baik pada hewan model maupun pada manusia. Proses selanjutnya, IFN $\gamma$ ini akan mengaktivasi makrofag.

Sebaliknya, peran sel $\mathrm{T}$ CD8 masih belum banyak diketahui, hal yang jelas adalah adanya antigen $M$. tuberculosis pada sitoplasma APC akan dipresentasikan melalui jalur MHC klas I pada sel T CD8. Dalam hal ini antigen difragmentasi oleh proteasome menjadi peptida-peptida dan selanjutnya ditranspor ke dalam RE. Disini peptida berikatan dengan MHC klas I, membentuk kompleks dan ditranspor ke permukaan sel untuk dipresentasikan. Mekanisme ini dapat dihambat oleh Brefeldin A, sebagai inhibitor transpor RE - Apparatus golgi. ${ }^{(5)}$ Mycobacterium yang berada di dalam fagosom (makrofag) tidak dipecah menjadi peptida, dalam hal ini adanya antigen terlarut di dalam sitoplasma menyebabkan induksi MHC klas I, sehingga pada keadaan ini tidak terdapat peran proteasome dan sirkulasi RE. Ini merupakan salah satu mekanisme alternatif dalam presentasi antigen pada MHC klas I. ${ }^{(5)}$

Peranan antibodi terhadap infeksi $M$. tuberculosis secara umum sangat kecil, mengingat infeksi bakteri ini bersifat intraseluler sehingga fungsi opsonin, netralisasi atau aktivasi komplemen yang umumnya diperantarai oleh antibodi terhadap bakteri ekstraseluler atau toksin menjadi sulit dilakukan. Beberapa penelitian memperlihatkan bahwa antibodi dapat meningkatkan kemampuan fungsional makrofag dalam membunuh bakteri M. tuberculosis. Dalam perkembangannya, penelitian antibodi lebih banyak ditujukan untuk kepentingan diagnostik. ${ }^{(6,7)}$

Berkaitan dengan latar belakang di atas, dilakukanlah penelitian secara in vivo dengan menggunakan binatang percobaan untuk melihat sejauh mana pengaruh rute pemberian vaksin BCG secara oral dan subkutan terhadap sistem imunitas humoral, seluler dan aktivitas fungsional makrofag.

\section{METODE PENELITIAN}

Penelitian ini merupakan penelitian eksperimental yang dilaksanakan dengan mengunakan desain post test only control group design

Populasi penelitian adalah tikus jantan galur wistar, sehat, umur \pm 4 bulan dengan berat badan $180-220$ gr 
yang dibagi atas 3 (tiga) kelompok dengan masing-masing 10 ekor tikus. Kelompoknya terdiri dari kelompok kontrol, kelompok perlakuan dengan BCG secara subkutan, kelompok perlakuan dengan BCG secara oral.

Hewan coba diadaptasikan selama 5 hari. Pemberian makanan dan minuman sesuai kebutuhan. Dua puluh ekor tikus diberikan vaksinasi dengan vaksin BCG dengan dosis $100 \mathrm{ul}$, yang terdiri dari 10 ekor per oral dan 10 ekor secara subkutan pada paha belakang bagian dalam.

Pemeriksaan limfosit $\mathrm{B}$ dan $\mathrm{T}$ dilakukan terhadap 3 (tiga) kelompok hewan coba yang tiap kelompok terdiri dari 10 ekor. Konsentrasi sel B dan T ditentukan pada interfase $85 / 100 \%$.

Isolasi makrofag intraperitoneal dihitung dengan menggunakan hemositometer. Uji fagositosis dilakukan terhadap makrofag yang sudah dikultur.

Antibodi diperiksa dengan menggunakan ELISA terhadap serum dari semua kelompok tikus (subkutan, oral dan kontrol), yang dilakukan pada hari ke-10 dan 20.

Hasil yang didapat dianalisa dengan menggunakan program SPSS 11.0. Evaluasi awal dan akhir menggunakan $t$ test berpasangan dan perbandingan antara CD4 dan CD8 dilakukan dengan independent $t$ test.

\section{HASIL DAN PEMBAHASAN \\ Hasil}

Respon imunitas humoral

Penilaian respon imun humoral didasarkan pada pembentukan antibodi, dalam hal ini konsentrasi Imunoglobulin $G$ dan jumlah isolasi sel limfosit B dari hewan coba. Penelitian ini ditemukan pada hari ke-10 paska vaksinasi rerata kadar antibodi dari kelompok yang diberikan vaksin BCG secara subkutan adalah OD $1.714 \pm$ 0.124 , sedangkan kelompok oral adalah $1.256 \pm 0.243$ dan pada kontrol kadar antibodi adalah $0.975 \pm 0.253$. Secara statistik ditemukan perbedaan kadar ketiga kelompok ( $\mathrm{p}<0.05)$. Perbedaan terbesar ditemukan antara kelompok subkutan dengan oral dan kontrol ( $\mathrm{p}<$ 0.05), sedangkan pada kelompok oral dan kontrol tidak ditemukan perbedaan yang bermakna $(p>0.05)$.

Hari ke-20 rerata antibodi pada kelompok BCG subkutan meningkat menjadi $1.912 \pm 0.325$, namun demikian secara statistik perbedaan ini tidak bermakna ( $p>0.05)$. Keadaan yang hampir sama juga ditemukan pada kelompok BCG oral, dimana kadar meningkat menjadi $1.293 \pm 0.144(\mathrm{p}>$ $0.05)$.

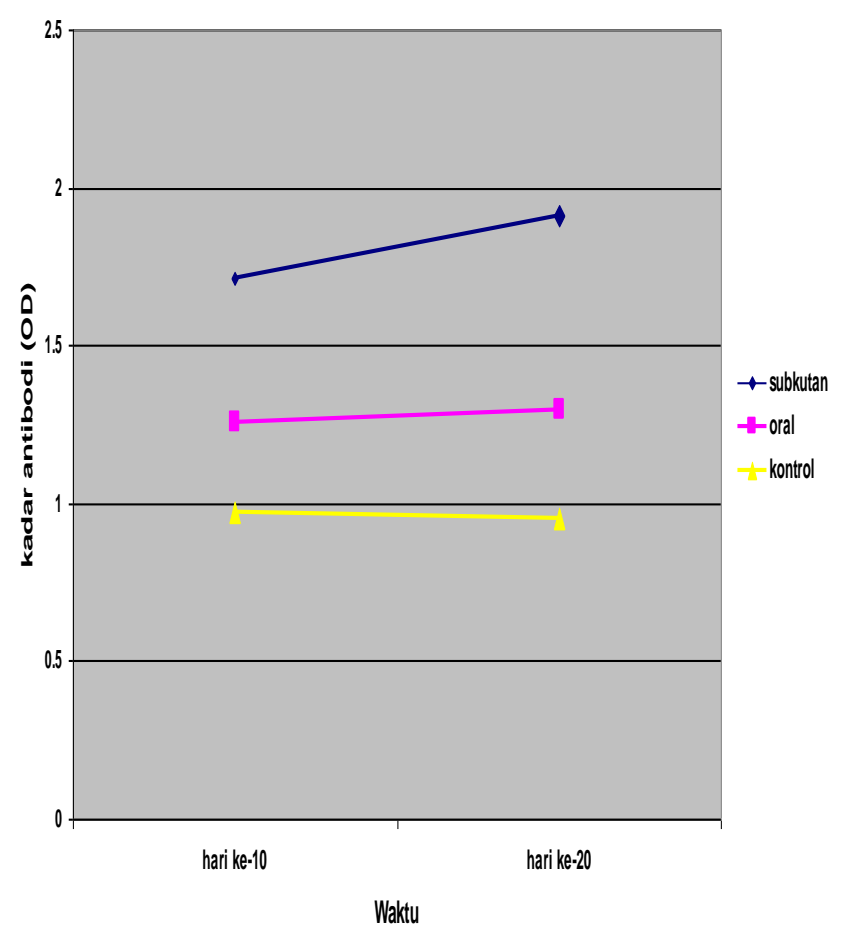

Gambar 1. Kadar antibodi (IgG) (OD) dari ketiga kelompok hewan coba $(p=0.000)$. Pemberian melalui subkutan memperlihatkan kadar yang lebih tinggi dibanding oral $(\mathrm{p}=0.006)$ dan kontrol $(\mathrm{p}=0.000)$. Tidak ada perbedaan yang bermakna antara pemberian oral dengan kelompok kontrol ( $p$ $=0.081$ ). 
Analisis dengan ficoll gradient besar dibanding dengan kelompok oral hari ke-10 memperlihatkan bahwa dan kontrol. Pada kelompok subkutan konsentrasi sel Limfosit $\mathrm{B}$ tertinggi didapatkan konsentrasi limfosit $\mathrm{T} 3.8 \mathrm{x}$ ditemukan pada kelompok subkutan, $10^{4} \mathrm{sel} / \mathrm{ml}$ sedangkan pada kelompok yaitu $4.5 \times 10^{3} \mathrm{sel} / \mathrm{ml}$. Jumlah ini oral dan kontrol, masing-masing adalah berbeda secara bermakna dengan yang $1.1 \times 10^{4} \mathrm{sel} / \mathrm{ml}$ dan $0.8 \mathrm{sel} / \mathrm{ml}$. Analisis ditemukan pada pada kelompok oral, statistik dengan one way Anova mem$2.6 \times 10^{3} \mathrm{sel} / \mathrm{ml}$ dan kontrol 2.2. $\times 10^{3}$ perlihatkan bahwa bahwa ditemukan $\mathrm{sel} / \mathrm{ml}$. Pada pemeriksaan hari ke-20 perbedaan yang signifikan antara tidak ditemukan perubahan konsentrasi konsentrasi limfosit $\mathrm{T}$ pada kelompok limfosit B dibandingkan dengan hari subkutan dengan kelompok oral ( $\mathrm{p}<$ ke-10, baik pada kelompok oral dan 0.05) dan kontrol ( $\mathrm{p}<0.05$ ), namun subkutan.

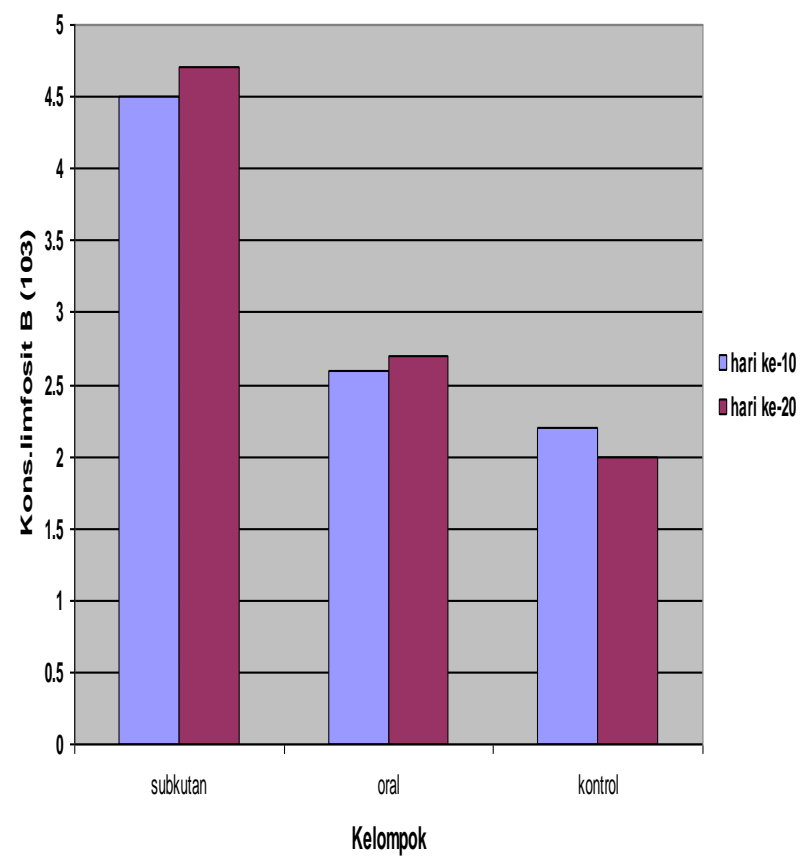

Gambar 2. Konsentrasi limfosit B dari ketiga kelompok hewan coba $(\mathrm{p}=0.000)$. Pemberian melalui subkutan memperlihatkan kadar yang lebih tinggi dibanding oral $(\mathrm{p}=0.000)$ dan kontrol $(\mathrm{p}=0.000)$. Tidak ada perbedaan yang bermakna antara pemberian oral dengan kelompok kontrol $(\mathrm{p}=0.137)$. Tidak terdapat perbedaan konsentrasi limfosit B antara hari ke10 dan 20 pada ketiga kelompok ( $p>0.05)$.

\section{Respon imunitas seluler}

Isolasi sel limfosit $\mathrm{T}$ dilakukan dengan ficoll gradient pada interfase $85 / 100 \%$. Pada penelitian ini didapatkan konsentrasi limfosit $\mathrm{T}$ pada kelompok hewan coba yang mendapatkan vaksin BCG secara subkutan lebih tidak ada perbedaan antara kelompok oral dengan kontrol $(\mathrm{p}>0.05)$.

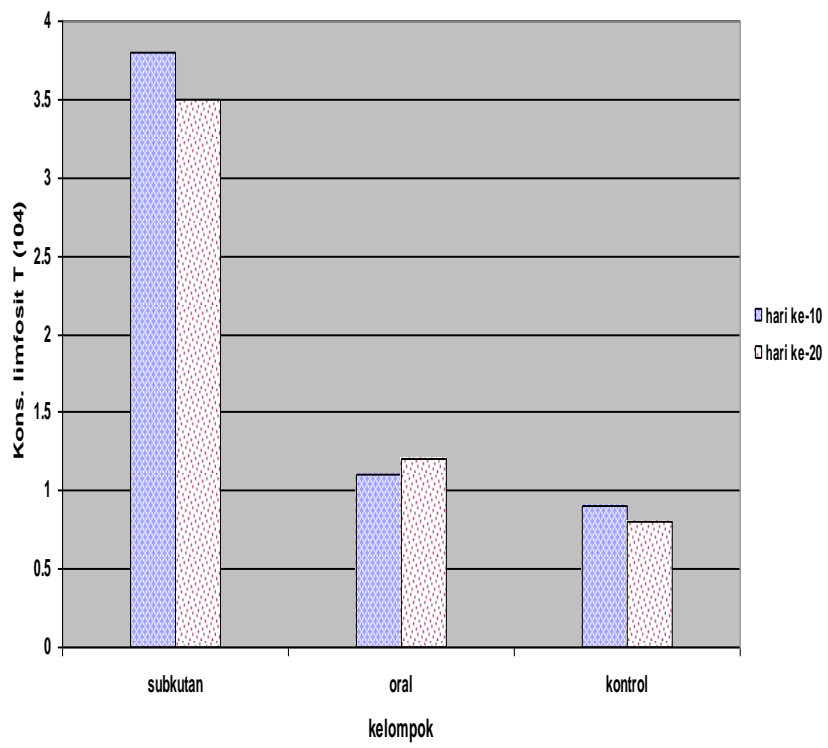

Gambar 3. Konsentrasi limfosit $\mathrm{T}$ dari ketiga kelompok hewan coba $(\mathrm{p}=0.000)$. Pemberian melalui subkutan memper-lihatkan kadar yang lebih tinggi dibanding oral $(\mathrm{p}=0.000)$ dan kontrol $(\mathrm{p}=0.000)$. Tidak ada perbedaan yang bermakna antara pemberian oral dengan kelompok kontrol $(p=0.385)$. Tidak ditemukan perbedaan konsentrasi limfosit $\mathrm{T}$ pada hari ke10 dan ke-20 pada ketiga kelompok.

\section{Respon makrofag}

Respon makrofag didasarkan pada kemampuan fagositosis dan jumlah partikel lateks yang difagosit oleh makrofag. Pada penelitian ini didapatkan kemampuan fagositosis makrofag yang diisolasi dari intraperitoneal ketiga kelompok 
berbeda secara bermakna, baik pada minggu ke-10 maupun ke-20 ( $\mathrm{p}<0.05$ ).

Kemampuan fagositosis makrofag kelompok subkutan adalah $62.5 \pm 6.8$ lebih tinggi dibanding kelompok oral $48.7 \pm 5.8$ dan kontrol $35.6 \pm 4.4$ pada minggu ke-10 dan pada minggu ke-20 meningkat menjadi $67.8 \pm 10.8$ pada subkutan, $55.3 \pm 7.2$ oral dan 34.7 pada kelompok kontrol. Namun demikian tidak ditemukan perbedaan yang bermakna antara kemampuan fagosit makrofag hari ke-10 dengan ke-20 pada kelompok subkutan dan oral ( $\mathrm{p}>0.05)$.

Rerata jumlah partikel lateks yang difagosit oleh makrofag ketiga kelompok juga tidak berbeda secara bermakna ( $p>0.05)$. Pada kelompok subkutan ditemukan jumlah partikel yang difagosit adalah $6.3 \pm 1.4$, kelompok oral adalah $5.6 \pm 2.1$ dan kontrol $4.7 \pm 2.3$.

Tabel 1. Rerata kemampuan fagositosis makrofag dan jumlah partikel lateks yang difagosit oleh makrofag pada kelompok subkutan, oral dan kontrol.

\begin{tabular}{l|l|c|c|c}
\hline \multirow{2}{*}{ Kelompok } & \multicolumn{2}{|c|}{ Fagositosis (\%) } & \multicolumn{2}{c}{ Jumlah fagosit } \\
\cline { 2 - 5 } & $\begin{array}{c}\text { Hari ke- } \\
\mathbf{1 0}\end{array}$ & $\begin{array}{c}\text { Hari } \\
\text { ke-20 }\end{array}$ & $\begin{array}{c}\text { Hari } \\
\text { ke-10 }\end{array}$ & $\begin{array}{r}\text { Hari } \\
\text { ke-20 }\end{array}$ \\
\hline Subkutan & $62.5 \pm 6.8$ & $48.7 \pm 5.8$ & $6.3 \pm 1.4$ \\
Oral & $6.2 \pm 1.5$ & & \\
Kontrol & $35.6 \pm 4.4$ & $67.8 \pm 10.8$ & $5.6 \pm 2.1$ \\
& $5.3 \pm 1.7$ & & \\
& $55.3 \pm 7.2$ & $34.7 \pm 5.1$ & $4.7 \pm 2.3$ \\
& $4.2 \pm 2.5$ & & \\
\hline
\end{tabular}

\section{Pembahasan}

Penelitian ini pada dasarnya untuk membandingkan pengaruh vaksinasi BCG terhadap tikus putih Rattus Norvegicus galur Wistar dari aspek imunologis, yaitu komponen imunitas humoral, seluler dan fungsi makrofag. Komponen humoral dinilai berdasarkan konsentrasi limfosit B dan kadar antibodi dalam bentuk OD, komponen seluler dalam bentuk jumlah limfosit $\mathrm{T}$ dan fungsi makrofag didasarkan pada kemampuan fagositosis makrofag.

Peranan antibodi terhadap infeksi $M$. tuberculosis masih belum banyak diketahui, pemahaman yang diterima saat ini bahwa antibodi menggambarkan tingkat daya tahan seseorang terhadap Tuberkulosis dan dijadikan sebagai salah satu sarana diagnostik Tuberkulosis. ${ }^{(6-8)}$

Pada penelitian ini terlihat bahwa hewan coba yang mendapat vaksin BCG subkutan mempunyai kadar antibodi yang lebih tinggi terhadap PPD $M$. tuberculosis dibandingkan dengan vaksin yang diberikan secara oral $(p<0.05)$. Sebaliknya hampir tidak ditemukan perbedaan kadar antibodi hewan coba yang mendapat vaksinasi BCG oral dengan kelompok kontrol. Keadaan ini kemungkinan berkaitan dengan 2 (dua) hal, yaitu pertama adanya kerusakan vaksin saat melewati saluran cerna sehingga induksi sistem imun lebih kecil, kedua berkaitan dengan antibodi yang terbentuk pada pemberian vaksin per oral lebih dominan pada mukosa yang terdapat di dalam darah.

Pada penelitian ini juga ditemukan bahwa hampir tidak ditemukan perubahan OD antibodi antara hari ke-10 dan ke-20 post vaksinasi, baik secara oral maupun subkutan. Keadaan ini berkaitan dengan periode aktivasi sistem imunitas adaptif yang terjadi pada hari ke-7 dan setelah hari ke-15 biasanya pembentukan antibodi mulai menunjukkan penurunan. Hal ini menyebabkan pemeriksaan antibodi hari ke-20 tidak menunjukkan perbedaan yang signifikan dibanding hari ke-10, walaupun kadar hari ke-20 lebih tinggi pada kedua metode vaksinasi.

Pada penelitian ini ditemukan jumlah sel Limfosit $\mathrm{T}$ terlihat lebih tinggi dibanding sel limfosit B, baik 
pada hari ke-10 maupun hari ke-20 ( $<$ < 0.05). Hal ini terlihat berkorelasi dengan banyak penelitian lain yang menjelaskan bahwa pada bakteri intraseluler, seperti $M$. tuberculosis, peranan sel limfosit $\mathrm{T}$, terutama subtipe sel Th akan menunjukkan pola yang lebih dominan. Sel $\mathrm{T}$ selanjutnya berdiferensiasi menjadi sel Th1 dan Th2. Sitokin Th1, seperti IFN- $\gamma$ akan menginduksi aktivasi makrofag. Peranan sel limfosit B yang berakhir dengan pembentukan antibodi umumnya lebih berperan pada bakteri ekstraseluler atau toksin. Antibodi dapat bekerja melalui berbagai mekanisme seperti netralisasi, opsonisasi, aktivasi komplemen, dan ADCC (antibody dependent cell mediated cytotoxicity). ${ }^{(9,10)}$

Jumlah sel limfosit $\mathrm{T}$ pada hari ke-20 post vaksinasi secara umum memperlihatkan peningkatan, namun secara statistik tidak menunjukkan perbedaan yang bermakna dengan limfosit $\mathrm{T}$ yang ditemukan pada hari ke$10(\mathrm{p}>0.05)$. Keadaan ini diduga berkaitan dengan periodisasi perkembangan sistem imunitas adaptif, dimana terjadi peningkatan yang cepat hingga hari ke-15 selanjutnya berkembang lebih lambat.

Pemeriksaan makrofag hari ke10 dan 20 pada dasarnya menggambarkan makrofag yang sudah teraktifasi oleh sitokin yang dihasilkan oleh sel Th1. Makrofag ini akan aktif untuk membunuh basil tuberkulosis melalui peningkatan kemampuan fagositosis produksi ROI, RNI dan mekanisme apoptosis. ${ }^{(10-13)}$

Pada penelitian ini terlihat peningkatan aktivitas makrofag hari ke20 dibanding hari ke-10 pada hewan coba yang mendapat vaksin BCG baik secara subkutan maupun oral, walaupun secara statistik peningkatan tersebut tidak berbeda secara bermakna ( $p$ >
0.05). Pola peningkatan makrofag ini pada dasarnya hampir sama dengan pola peningkatan sel limfosit $\mathrm{T}$, dimana subtipe sel Th1 akan menghasilkan sitokin aktivasi makrofag.

Secara keseluruhan dapat dilihat bahwa pemberian vaksin BCG secara subkutan terlihat lebih baik dibanding dengan pemberian per oral berdasarkan produksi antibodi, aktivitas limfosit B, aktivitas limfosit $\mathrm{T}$ dan kemampuan fagositosis makrofag. Fenomena ini pada dasarnya sedikit berbeda dengan teori imunitas mukosa yang dikembangkan oleh beberapa peneliti akhir-akhir ini. Chen dkk (2004) dan Williams dkk (2000) memperlihatkan induksi mukosa pada pemberian vaksin BCG akan memberikan efek proteksi yang lebih baik dibanding dengan pemberian secara subkutan. ${ }^{(14,15)}$

Sejumlah Mitrucker dkk (2007) memperlihatkan bahwa pemberian vaksin BCG secara intragastrik (ig) memberikan efek proteksi yang lebih baik terhadap infeksi $M$. tuberculosis pada paru, limfa dan hati dibandingkan pemberian secara intravena (iv) dilihat dari aspek pertumbuhan bakteri dan produksi IFN- $\gamma$. Perbedaan penelitian ini dengan Mitrucker kemungkinan terkait dengan cara pemberian vaksin BCG, dimana Mitrucker memberikan langsung dengan sonde sebaliknya penelitian ini hanya memberikan per oral biasa disamping hewan coba yang juga berbeda. ${ }^{(16)}$

\section{Kesimpulan}

Pada penelitian ini dapat disarankan hal berikut :

1. Pemberian vaksin BCG secara oral akan meningkatkan respon imunitas tubuh dilihat dari aspek sel limfosit B, T, pembentukan antibodi dan kemampuan makrofag 
2. Pemberian vaksin BCG secara subkutan akan meningkatkan respon imunitas tubuh dilihat dari aspek sel limfosit $\mathrm{B}, \mathrm{T}$, pembentukan antibodi dan kemampuan makrofag.

3. Pemberian vaksin BCG secara subkutan lebih baik dibanding pemberian per oral ditinjau dari respon imunitas tubuh.

\section{KEPUSTAKAAN}

1. Doherti, M.T and Andersen, P. Vaccines for Tuberculosis: Novel Concepts and Recent Progress. Clin.Microbiol. Rev, 2005; 18(4): 687-702.

2. Murray, R.A., Mansoor, N., Harbacheuski, R., Soler, J.,Davids, V., Soares, A., Hawkridge, A., et al. Bacillus Calmette Guerin Vaccination of Human Newborns Induces a Specific, Functional $\mathrm{CD}^{+} \mathrm{T}$ Cell Response1. $J$. Immunol 2006;177:5647-51.

3. Brennan, M. The tuberculosis vaccine challenge. Tuberculosis, 2005; 8:7 - 12 .

4. Gray, J.W. Chilhood tuberculosis and its early diagnosis. Clin. Biochem 2004;37: 450 - 5.

5. Canaday, D.H., Ziebold,C., Noss, E.H., Chervenak, K.A., Harding, C.V., and Boom, W.H. Activation of Human $\mathrm{CD}^{+} \alpha \beta \mathrm{TCR}^{+}$Cells by Mycobacterium tuberculosis Via an Alternate Class I MHC AntigenProcessing Pathway. J. Immunol, 1999; 162:372-9.
6. Bothamley, L. Tuberculin testing before BCG vaccination. BMJ, 2003; 327:923-4.

7. Daniel TM dan Debanne SM. 1987. The serodiagnosis of tuberculosis and other mycobacterial diseases by enzyme-linked immunosorbent assay. Am Rev Respir Dis, 1987; 135:1137-51.

8. Singh, KK., Dong, Y., Hinds, L. Combined use of serum and urinary antibody for diagnosis of tuberculosis. J Infect Dis, 2003; 188:371-7.

9. Kaufman, S.H.E. Protection againts tuberculosis: cytokines, T cells, and macrophages. Ann.Rheum Dis, 2002; 61(2):54-8.

10. Cowley, S.C and Elkins, K.E. $\mathrm{CD} 4^{+} \mathrm{T}$ Cells Mediate IFN- $\gamma$ Independent Control of Mycobacterium tuberculosis Infection Both In Vitro and In Vivo. J. Immunol.2003; 171: 468999.

11. van Crevel, R., Ottenhoff, T.H.M and Meer, J.W.M. Innate immunity to Mycobacterium tuberculosis. Clin.Microbiol Rev, 2002; 15: 294 -309 .

12. Choi, H.S., Rai, P.R., Chu, H.W., Cool, $\mathrm{C}$ and Chan, E.D. Analysis of Nitric Oxide Synthase and Nitrotyrosine Expression in Human Pulmonary Tuberculosis. Am J Respir Crit Care Med, 2002; 166: 178-86. 
13. Collazo, E.L., Hortelano, S., Rojas, $A$ and Bosca, L. Triggering of Peritoneal Macrophages with IFN$\alpha / \beta$ Attenuates the Expression of Inducible Nitric Oxide Synthase Through a Decrease in NF- $\kappa \mathrm{B}$ Activation. The J. Immunol, 1998; 160: 2889-95.

14. Chen, L., Wang, L., Zganiacz, A and Xing, Z. Single Intranasal Mucosal Mycobacterium bovis BCG Vaccination Confers Improved Protection Compared to Subcutaneous Vaccination against Pulmonary Tuberculosis. Infect. Immun, 2004; 72: 238-46.
15. Williams, A., Davies, A., Marsh, P.D., Chambers, M.A and Hewinson, R.G. Comparison of the Protective Efficacy of Bacille Calmette-Gue'rin Vaccination against Aerosol Challenge with Mycobacterium tuberculosisand Mycobacterium bovis Clin Infect Dis, 2000;30:299-301.

16. Mittrucker, H.W., Steinhoff, U., Kohler, A., Krause, M., Lazar, D., Mex, P., et al. 2007. Poor correlation between BCG vaccination-induced $\mathrm{T}$ cell responses and protection against tuberculosis. PNAS, 2007; 104: 12434-9. 